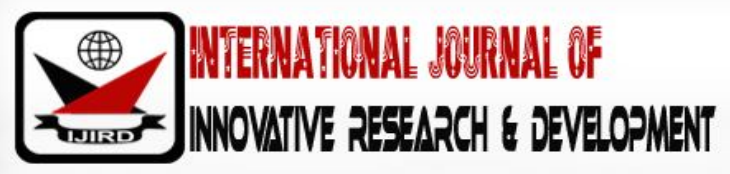

ISSN 2278 - 0211 (Online)

\section{Strategic Customer Relationship Management Practices: Employees' Perception of its Influence on Competitive Advantage and Organizational Performance in the Nigerian Banking Sector}

Opaleye, MuyiwaAdeleke
Department of Business Administration, The Polytechnic, Ile-Ife. Osun State, Nigeria
Egwu, Bridget Uchenna
Department of Business Administration, The Polytechnic, Ile-Ife. Osun State, Nigeria
Adeyemi, Omolade Sunday
Department of Business Administration, Oduduwa University, Ipetumodu.Osun State, Nigeria

\begin{abstract}
:
The study aimed at examining employees' perception of the influence of strategic customer relationship management practices (SCRMPs) on competitive advantage (CA) and organizational performance (OP). The SCRMPs was captured through customer focus, knowledge management, CRM organizations and technology based CRM; CA was measured through customer satisfaction and customer retention; while profitability and market share were used to measure organizational performance. A descriptive survey design was adopted; data were gathered through a self-structured questionnaire administered to 240 staff of commercial banks in Ibadan, Oyo state out of which the response of 200 staff were considered useful for the study.Data gathered was coded and entered into the Statistical Package Software for Social Science (SPSS) version 20 and the method of linear regression was used to test the hypotheses formulated. The findings of the study indicate that, there is a strong influence of SCRMPs on CA and OP with $r$ value of 0.739 and 0.921 respectively. The relationship between SCRMPs and OP is stronger (0.921) compared to that of CA (0.737). Also, the result of the analysis shows that there is a strong relationship between CA and OP of commercial banks in Oyo state with $r$ value of 0.797 . Based on results of the analysis, organizations should not relent in the activities of managing their relationship with customers through appropriate SCRM practices for better CA and better OP.
\end{abstract}

Keywords: Strategic customer relationship management, competitive advantage, and organizational performance

\section{Introduction}

Today's organizations are faced with numerous challenges such as increased uncertainty, cutthroat competition, financial crises, technological advancement, labour turnover, to mention but a few, posing threat on their survival and growth. Business environment keep changing day by day and Olanipekun (2014) identified globalization of trade, increased size and influence of corporate organizations, the repositioning of government and the rise in the strategic importance of stakeholder's relationships, knowledge, and brand reputation as key drivers of this change. As organizations desire to survive in the midst of these aforementioned challenges, a necessity is placed on such organizations either manufacturing or service provider to objectively evaluate both the internal and external conditions of its business for appropriate action. Aremu (2010) affirmed that organizations is mandated to clearly defined strategy that will leadto enthusiasm among various stakeholders which includes shareholders, suppliers, creditors, customers, and employees and so as to promote commitment that will enhance better business performance. This implies that, it becomes imperative for organizations to embrace the process and approach of specifying an organization's objectives, developing policies and plans to achieve and attain these objectives, and allocating resources so as to implement the policies and plans.

With all indications, there is a wide gap between organizations that plan ahead and those that do not. A good performance achieves continuous improvement in only those organizations, where every employee gives his best achievement priority to corporate goals and business strategy.In buttressing this, Sharabati and Fuqaha (2014) opined that, in this age of globalization, strategic management has been considered as the most important practice which distinguishes organizations 
from each other's. Forward looking planning and careful evaluation of organization priorities enhances effective control of future, which is necessary in the fast changing business landscape of the 21 st century.

The nature of banking service most especially in Nigeria, places a necessity on management in building up an image of respectability, capability and reliability through adoption and implementation of appropriate strategic customer relationship management practices so as to have a solid competitive advantage and better organizational performance.

\section{Statement of the Research Problem}

Many organizations are dying day by day as a result of their nonchalant attitude towards their customers 'expectations. As customer is the main axis of activities of organization, survival of organization largely depends on its ability to identify and attract new customers alongside with the maintenance of the existing customers (Elahietal., 2005).Yunjaet al., (2004) in their study stressed that, the costs of attracting new customers is five times cost of maintaining existing customers. Therefore, organization should focus on how to increase the share of customers by putting in place appropriate strategic customer relationship management practices capable of enhancing competitive advantage and eventually lead to better organizational performance.

\section{Study Objectives}

Generally, the study aimed to examine employees' perception of the influence of Strategic Customer Relationship Management Practices on Competitive Advantage and organizational Performance in the Nigerian banking sector. Specifically, the study attempt to:

- Determine, if strategic customer relationship management practices (SCRMPs) have any influence on competitive advantage (CA) of commercial banks in Oyo state;

- Evaluate the influence of strategic customer relationship management practices (SCRMPs) on organizational performance (OP) of commercial banks in Oyo state; and

- Ascertain if competitive advantage (CA) have any influence on organizational performance (OP) of commercial banks in Oyo state.

\section{Research Questions}

In order to achieve the set three objectives, the following research questions become pertinent:

- Does strategic customer relationship management practices (SCRMPs) have any influence on the competitive advantage (CA) of commercial banks in Oyo state?

- Of what influence does strategic customer relationship management practices (SCRMPs) have on the organizational performance (OP) of commercial banks in Oyo state?

- Does competitive advantage (CA) have any influence on organizational performance (OP) of commercial banks in Oyo state?

\section{Research Hypotheses}

The following hypotheses were stated in a null form to be tested.

- $\mathbf{H}_{0}$ 1: Strategic customer relationship management practices (SCRMPs) have no significant influence on competitive advantage (CA) of commercial banks in Oyo state.

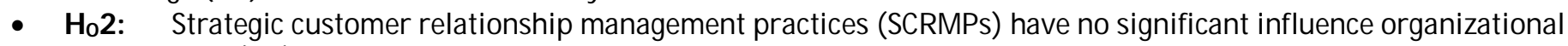
performance (OP) of commercial banks in Oyo state.

- Ho3: Competitive Advantage (CA) has no influence on organizational performance (OP) of commercial banks in Oyo state.

\section{Conceptual Framework}

The study contains three variables. The independent variable (strategic customer relationship management practices) wascaptured through customer focus, knowledge management, CRM organizations; and technology based CRM. Also, competitive advantage which is one of the dependent variable has customer satisfaction and customer retention as its constructs while organizational performance the second dependent variable has profitability and market share as it measures. 


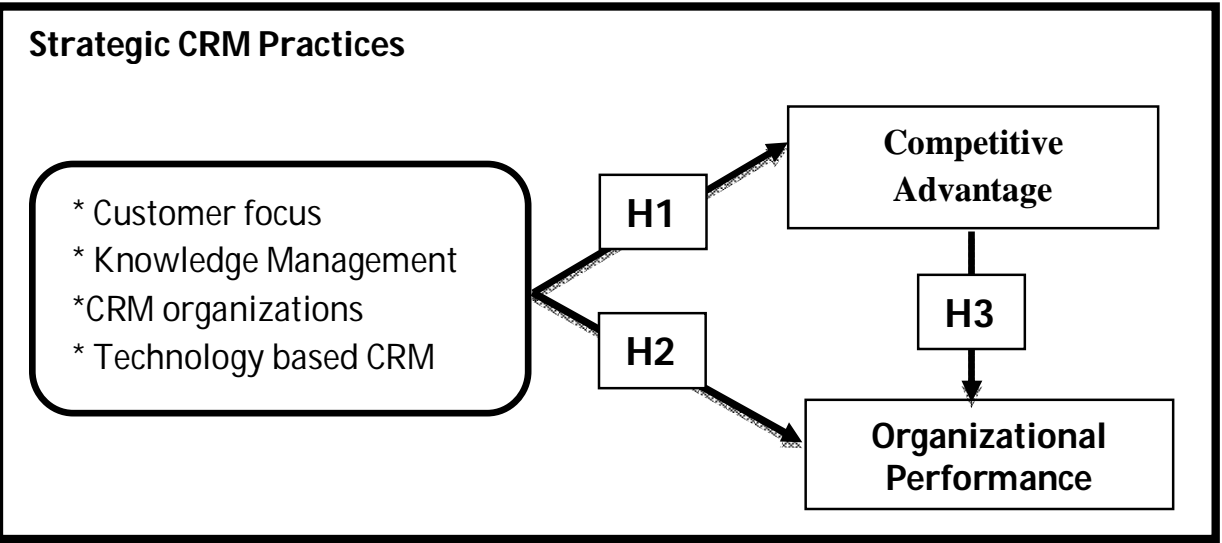

Figure1: Conceptual Framework

Source: Author's Initiative, 2017

\section{Literature Review}

\subsection{Strategic Customer Relationship Management Practices}

The competitive nature of the business environment saddled management of various organizations with the responsibility of treating customer as king because there is no business without customer. Also, Dowling (2002) stressed that establishing a sustainable relationship with customers is the cornerstone for obtaining loyal customers who are much more profitable than non -loyal ones. Based on the above view, adoption and implementation of strategic customer relationship management (SCRM) becomes an issue of concern both in service and manufacturing industry. Sin et al., (2005) viewed CRM as a comprehensive strategy and process that enables an organization to identify, acquire, retain and nurture profitable customers. CRM create a customer oriented organization that maximizes customer value and long term organizational profitability through realization of mutual beneficial, durable relationships with customers (Zablahet al., 2004; Shah et al., 2006).

Based on critical review of past related studies (Coltman, 2007, Xu et al., 2007; Sin et al., 2005; Yim et al., 2005), it can be said that CRM is a multi-dimensional construct consists of four broad behavioral dimensions. These behavioral dimensions are: customer orientation, Knowledge management, CRM organizations, and Technology based CRM.

\subsection{Customer Orientation}

This is the part of the organizational culture that provides implicit values and beliefs on which norms of accepted behavior are based (Bentum and Stone 2005).Pelham and Kravitz (2008) described it as activities focused with regards to determining and understanding the various needs of the potential customers and initiating the firm's reaction to meeting and satisfying those needs and expectations above that of competitors. In addition, it is an organizational stance in which all aspects of a company's production and delivery of goods or services are directed by the best interests of the customers.Zhu and Nakata (2007) in their study found that customer orientation enhances market performance which in turn influences financial performance. Also, Boateng, (2014) affirmed that customer orientation has a positive relationship with selected banks' performance.

\subsection{Knowledge Management}

This is another dimension that plays a significant role in customer relationship management. The management of knowledge has generated considerable interest in business and management circles due to its capability to deliver to organisations, strategic results relating to profitability, competitiveness and capacity enhancement (Chua, 2009; Jeon, Kim and Koh 2011).Harris (1999) defined knowledge management as the process through which information related to technology and market are converted to decisions in such a strategic manner, which fulfills the customer needs according to the customer behavior and satisfaction. Hislop (2013) sees knowledge management as an umbrella term which refers to any deliberate efforts to manage the knowledge of an organization's workforce, which can be achieved via a wide range of methods. Knowledge management increases customer loyalty and repeat business which are very important priorities under the chosen competitive strategy (Sousa, 2003); resulting into positive impact on organization's performance (Akroushet al., 2011).

\subsection{CRM Organizations}

This has been described as the supporting organization structure, incentives, resources allocation, and management controls that enable building and sustaining customer relationships (Day and Van den, 2002; Jayachandran, et al., 2005). To 
respond effectively to customers' need, organization must align their structure and management processes with their market goals which eventually lead to superior performance (Reinartzet al., 2004). Furthermore, organizational structure needs to be redesigned with appropriate and effective line of communication (Liu, 2007). Organization must develop a climate for service in work which includes: provision of customer satisfaction tracking and complaint management system, inspiring service leadership, appropriate reward system and provision of staff with modern tools and technology for service employee to display their customer oriented behavior (Mechinda and Patterson, 2011; Dutu and Halmajan, 2011).

\subsection{Technology Based CRM}

This concerns an integration of marketing strategies and marketing practices through ERP Softwares that assist companies to manage, record and evaluate interactions between companies and their customers or the purpose of enhancing the relationships between companies and customers. According to Jayachandranet al., (2005)technology based CRM consists of all the information systems used to support front office functions (sales, customer service, and marketing) and back office applications that deal with data integration and analysis. Numerous studies affirmed both direct and indirect impact of CRM technology on performance (Kasim and Minai 2009; Ata and Toker, 2012; Abdul Alemet al., 2013).

\subsection{Competitive Advantage}

The nature of the competitive environment where business operates makes the concern for competitive advantage a vital issue; and an idea very much at the heart of the strategic management literature (Cousins, 2005; Porter and Kramer, 2006; Liao and $\mathrm{Hu}$, 2007). Providing a precise definition of competitive advantage is a difficult task (Hakkak and Ghodsi, 2015) but viewing from the field of competitive strategy and in the context of value creation, competitive advantage is whatever causes revenues increase over expenses (Rumelt, 2003). It also means firm capability to produce goods or services that the customers seem them more valuable than those produced by other competitors' (Garth, et al., 2001) and the extent to which an organization is able to create a defensible position over its competitors (Barney 1991). Clulowet al., (2003) stressed that a firm is said to have a competitive advantage when it is implementing a value creating strategy not simultaneously being implemented by any current or potential player. In addition, there is competitive advantage when customer perceives a consistent difference in important attributes between the producer's products or services and those of its competitors (Agha, et al., 2012).

Although there is a quite consistent empirical literature identifying price/cost, quality, delivery, and flexibility as important competitive capabilities or measures (Tracey, et al., 1999) but for the purpose of this study, customer satisfaction and customer retention shall be used as measures.

\subsection{Organizational Performance}

Performance of the organization refers to those attitudes' that have been assessed or measured as to their contribution to organizational goals (Cook and Hunsaker, 2001). Organizational performance has been measured by academicians and practitioners from different perspectives. Adieleet al., (2011) affirmed that performance indicators range from both financial and non-financial angles while some conceptualized performance from marketing perspective using indicators such as profitability, market share and sales volume (Asiegbu, et al., 2011; O'sullivan, et.al., 2009). In addition, Stock etal., (2000) stressed that a number prior studies have measured organizational performance using both financial and market criteria, including return on investment (ROI), market share, profit margin on sales, the growth of ROI, the growth of sales, and the growth of market share. In line of the above, this study shall also view organizational performance from both financial and market perspective using profitability and market share as measures respectively.

\section{Methodology}

Based on the empirical nature of this study, coupled with the view of achieving the set three objectives and providing answers to the research questions formulated, a descriptive survey design which measured two main variables (independent variable and dependent variable) is adopted. The adoption of this type of design is borne out of the fact that, it enables the researcher to have direct contact with the respondents. The independent variable (Strategic customer relationship management practices (SCRMPs) was captured by four sub-variables (customer orientation, Knowledge management, CRM organizations, and Technology based CRM.) while competitive advantage, a dependent variable was captured by two subvariables (customer satisfaction and customer retention). Also, the second dependent variable (organizational performance) was captured by two sub-variables (profitability and market share).

\subsection{Study Area}

The study was carried out in all the majorbranch of the 24 commercial banks in Ibadan, the capital of Oyo state, Nigeria. 


\subsection{Study Population and Sampling Technique}

Borrowing from the memory of the past, only 24 commercial banks survived the recapitalization hurdle in the late 2005 to early 2006. All these banks have multiple branches in Ibadan, the state capital of Oyo state but for the purpose of this study, major branch of each commercial bank in Ibadan shall be considered.

Furthermore, 10 regular staff was chosen randomly from each bank leading to a total number of 240 staff constituting total sample size of the study.

\subsection{Data Collection Instrument}

The study adopted primary source of data collection where a self-structured questionnaire was design to gather relevant data. The instrument was designed in two parts. Part I contains questions relating to demographic information of the respondents while part II focuses on questions relating to the variables of the study. The questions on the part II of the questionnaire were structured in Five-point Likert type ranging from stronglydisagree (1)", "disagree (2)", "undecided (3), "agree (4)", and "strongly agree (5)" so as to reduce the statistical problems of extreme skewness.

\subsection{Reliabilityand Validity of Research Instrument}

Mugenda and Mugenda (2003) described the reliability of research instrument as the degree to which the instrument used in the study yield consistent results or data after repeated trials.In ascertaining the reliability of the research instrument, a pilot-test was conducted where the instrument was administered twice on 8 regular staff of 5 selected commercial banks in Ile-Ife, Osun state, Nigeria. Cronbach's alpha coefficient was used and yielded a coefficient of 0.723 at 0.0.5 level of significant, which was considered adequate and acceptable for the study based on Sekaran, (2003) affirmation that reliabilities less that 0.60 are considered poor, those in the 0.7 range acceptable and those over 0.8 are good. Orodho (2004) described validity as the extent to which a measuring instrument provides adequate coverage of the topic under study or the degree of relevance the instruments are towards the research. In this study, both face and content validity of the instrument were ascertained bypresenting the instrument to two senior colleagues for appropriate correction.

\subsection{Data Analysis}

Data gathered was coded and entered into the Statistical Package Software for Social Science (SPSS) version 20 and the method of linear regression was used to test the three hypotheses formulated for the study.

\section{Findings and Testing of Hypotheses}

\subsection{Preliminary Findings}

Out of the 240 questionnaire administered by the researcher and his research assistants, 212 questionnaire were returned out of which 200 questionnaire were considered useful for the study.

From the findings, 117 respondents representing 58.5\% were male while 83 respondents representing $41.5 \%$ were female. This indicates that more male staff participates in the study than the female staff. Also, the findings of age distribution of the respondents shows that age bracket of $21-30$ years had $45.7 \%$, followed by $31-40$ years (40.8\%), $41-50$ years $(7.3 \%)$ and 51 years above $(6.2 \%)$ of the sample. From the finding, it shows that, majority of the respondents $(45.7 \%)$ were in the age bracket of 21-30 years.

The finding further revealed that $19.5 \%$ of the total respondents had post graduate qualifications, $59.1 \%$ had degree, $19.5 \%$ had diploma while $1.9 \%$ had other qualifications. This implies that majority of the respondents could respond the questions asked accordingly. As regard years of work experience, $24.5 \%$ of the respondents had been working for over 6 years, $75.2 \%$ had been working for a period of 4-6 years and $0.3 \%$ had been working between 1-3 years.

\subsection{Hypothesis Testing}

The first objective of the study was to examine if strategic customer relationship management practices (SCRMPs) have any influence on competitive advantage (CA) of commercial banks in Oyo state. In order to examine this, the method of linear regression was used to test the hypothesis and the result obtained is presented below:

- Ho1: Strategic customer relationship management practices (SCRMPs) have no significant influence on competitive advantage (CA) of selected commercial banks in Oyo state.

\begin{tabular}{|c|c|c|c|c|c|}
\hline & R & R square & Adjusted R square & F & P value \\
\hline $\begin{array}{c}\text { Strategic customer } \\
\text { relationship management } \\
\text { practices (SCRMPs) }\end{array}$ & 0.739 & 0.547 & 0.545 & 299.217 & 0.000 \\
\hline
\end{tabular}

Table 1

Dependent Variable: Competitive Advantage 


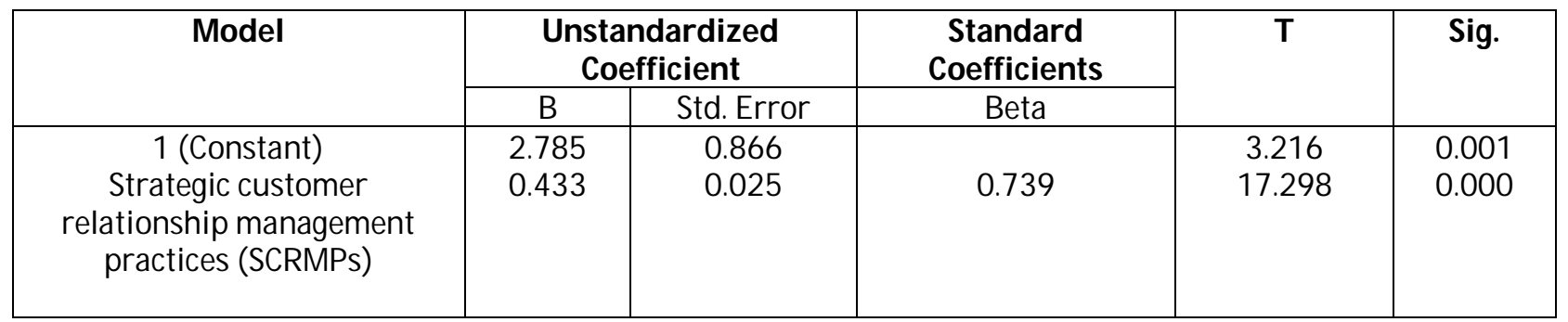

Table 2: Coefficients Table of Regression Model

Predictor: Strategic Customer Relationship Management Practices (SCRMPs)

Dependent Variable: Competitive Advantage

Source: Survey Data, (2017)

Table 2 above shows that $r$ value (0.739) is higher than the regular value of 0.5 which means there is a strong relationship between the independent and dependent variables i.e.strategic customer relationship management practices and Competitive Advantage. From the results, $54.7 \%$ of industry competitive advantage is based on Strategic customer relationship management practices (SCRMPs) and the remaining $45.3 \%$ is upon other factors not included in the study model.Based on the fact that, the $\mathrm{P}$ value of the results is 0.000 which is less than 0.05 , the hypothesis 1 is hereby rejected. It can therefore be concluded that Strategic customer relationship management practices (SCRMPs) have significant influence on competitive advantage (CA) of commercial banks in Oyo state.

The Second objective of the study was to evaluate the influence of Strategic customer relationship management practices (SCRMPs) on organizational performance (OP) of commercial banks in Oyo state. To achieve this, the method of linear regression was used to test the hypothesis and the result obtained is presented below:

- Ho2: Strategic customer relationship management practices (SCRMPs) have no significant influence on organizational performance (OP) of commercial banks in Oyo state.

\begin{tabular}{|c|c|c|c|c|c|}
\hline & R & R square & Adjusted R square & F & P value \\
\hline $\begin{array}{c}\text { Strategic customer } \\
\text { relationship management } \\
\text { practices (SCRMPs) }\end{array}$ & 0.921 & 0.848 & 0.847 & 138.383 & 0.000 \\
\hline
\end{tabular}

Table 3: Dependent Variable: Organizational Performance

\begin{tabular}{|c|c|c|c|c|c|}
\hline \multirow{2}{*}{ Model } & \multicolumn{2}{|c|}{$\begin{array}{c}\text { Unstandardized } \\
\text { Coefficient }\end{array}$} & $\begin{array}{c}\text { Standard } \\
\text { Coefficients }\end{array}$ & T & Sig. \\
\cline { 2 - 4 } & B & Std. Error & Beta & & \\
\hline $\begin{array}{c}\text { 1 (Constant) } \\
\text { relatiogic customer } \\
\text { practices (SCRMPs) }\end{array}$ & 5.149 & 0.793 & 0.921 & 6.489 & 0.000 \\
& 0.853 & 0.023 & & & \\
\hline
\end{tabular}

Table 4: Coefficients Table of Regression Model

Predictor: Strategic Customer Relationship Management Practices (SCRMPs)

Dependent Variable: Organizational Performance

Source: Survey Data, (2017)

Table 4 above shows that $r$ value (0.921) is higher than the regular value of 0.5 which means there is a strong relationship between the independent and dependent variables i.e.strategic customer relationship management practices (SCRMPs) and Organizational performance. From the results, 84.8\% of organizational performance (OP) is based on strategic customer relationship management practices (SCRMPs) and the remaining $15.2 \%$ is upon other factors not included in the study model. Based on the fact that, the P value of the results is 0.000 which is less than 0.05 , the hypothesis 2 is hereby rejected. Therefore, it can be concluded that strategic customer relationship management practices (SCRMPs) have significant influence on organizational performance (OP) of commercial banks in Oyo state.

- Ho3: Competitive Advantage (CA) has no significant influence on organizational performance (OP) of commercial banks in Oyo state. 


\begin{tabular}{|c|c|c|c|c|c|}
\hline & R & R square & Adjusted R square & F & P value \\
\hline Competitive Advantage & 0.797 & 0.635 & 0.633 & 431.173 & 0.000 \\
\hline
\end{tabular}

Dependent Variable: Organizational Performance

\begin{tabular}{|c|c|c|c|c|c|}
\hline \multirow{2}{*}{ Model } & \multicolumn{2}{|c|}{$\begin{array}{c}\text { Unstandardized } \\
\text { Coefficient }\end{array}$} & \multirow{2}{*}{$\begin{array}{c}\text { Standard } \\
\text { Coefficients }\end{array}$} & \multirow{2}{*}{ Tig. } \\
\cline { 2 - 4 } & B & Std. Error & Beta & & \\
\hline 1 (Constant) & 0.306 & 0.841 & 0.797 & 20.765 & 0.717 \\
Competitive Advantage & 0.504 & 0.024 & & & \\
& & & & & \\
\hline
\end{tabular}

Table 6: Coefficients Table of Regression Model

Dependent Variable: Organizational Performance

Source: Survey Data, (2017)

From table 6 above, the results of the analysis carried out in SPSS shows that $r$ value $=0.797$. This $r$ value is higher than the regular value of 0.5 , which indicate that there is a strong relationship between the two dependent variables i.e. competitive advantage and organizational performance. From the results $63.5 \%$ of organizational performance is due to competitive advantage (CA) and the remaining $36.5 \%$ is upon other factors. Based on the fact that, the P value of the results is 0.000 which is less than 0.05 , the hypothesis 3 is hereby rejected. Therefore, it can be concluded that competitive advantage (CA) has significant influence on organizational performance (OP) of commercial banks in Oyo state.

\section{Discussion and conclusion}

This study examined employees' perception of the influence of Strategic customer relationship management practices on competitive advantage and organizational performance in the Nigerian banking sector. After all the data analysis and calculation, it is found that there is a strong relation of Strategic customer relationship management practices to competitive advantage and organizational performance with $\mathrm{r}$ value of 0.739 and 0.921 respectively. The relationship between strategic customer relationship management practices (SCRMPs) and organizational performance is stronger (0.921) compared to that of competitive advantage (0.737). Also, the result of the analysis shows that there is a strong relationship between competitive advantage (CA) and organizational performance (OP) of commercial banks in Oyo state with r value of 0.797.

Based on the finding of this study, it is concluded that Strategic customer relationship management practices (SCRMPs) have significant influence on both competitive advantage (CA) and organizational performance (OR) of commercial banks in Oyo state. This implies that, organizations should not relent in the activities of managing their relationship with customers through appropriate practices for better competitive advantage and performance. Also, the result of the study indicates thatcompetitive advantage (CA) influence organizational performance (OP) of commercial banks in Oyo state positively.

\section{References}

i. Abdul Alem M., Basri, R., \&Shaharuddin, T. (2013) Assessing the influence of customer relationship management (CRM) dimensions on organization performance: An empirical study in the hotel industry. Journal of Hospitality and Tourism Technology, 4(3), 228-247.

ii. Adiele, K.C., John, M., Didia, JUD (2011). The impact of corporate citizenship on business performance: Marketing Implications for Nigerian Organizations. Benin J Soc. Sci.,19(1 \& 2), 319-330.

iii. Agha, S., Alrubaiee, L., \&Jamhour, M. (2012). Effect of core competence on competitive advantage and organizational performance. International Journal of Business and Management, 7(1), 192-204.

iv. Akroush, N.M., Dahiyat, E.S., Gharaibeh, S.H., \& Abu-Lail, N.B. (2011), Customer relationship management implementation: An investigation of a scale's generalizability and its relationship with business performance in a developing country context. International Journal of Commerce and Management, 21(2), 158-191.

v. Armstrong, M. (2006). A handbook of human resource management practice (10 th ed.). London: Kogan Page Publishing

vi. Asiegbu, F.I., Awa, H.O., Akpotu, C., \&Ogbonna, U.B. (2011). Sales force competence development and marketing performance of industrial and domestic products firms in Nigeria. Far East J Psychol. Bus., 2(3), 43-59.

vii. Ata, U. Z., \&Toker, A. (2012). The effect of customer relationship management adoption in business-to-business markets. Journal of Business \& Industrial Marketing, 27(6), 197-507.

viii. Barney, J. (1991). Firms resources and sustained competitive advantage. Journal of Management, 17(1), 791- 400. 
ix. Bentum, R. V., \& Stone, M. (2005). Customer relationship management and the impact of corporate culture: A European study. Journal of Database Marketing \& Customer Strategy Management, 13(1), 28-54.

x. Boateng, I.A. (2014). Effect of customer relationship management on the performance of banking services in Ghana. Journal of Contemporary Integrative Ideas, 2(1), 13-25.

xi. Chua, A.Y. K. (2009). The dark side of successful knowledge management initiatives. Journal of Knowledge Management, 13(4), 32-40.

xii. Clulow, V., Gerstman, J., \& Barry, C. (2003). The resource-based view and sustainable competitive advantage: The case of a financial services firm. Journal of European Industrial Training, 27(5), 220-232.

xiii. Coltman, T. (2007). Why build a customer relationship management capability? Journal of Strategic Information Systems,16(3), 301-320.

xiv. Cook, C. W., and Hunsaker, P.L. (2001). The Management and Organization Behaviour (3rded.). New York: McGraw-Hill. xv. Cousins, P.D. (2005). The alignment of appropriate firm and supply strategies for competitive advantage. International Journal of Operations \& Production Management, 25(5), 403-428.

xvi. Day, G. S., \&Vanden B. C. (2002). Superiority in customer relationship management: consequences for competitive advantage and performance. Report No. 02-123. Cambridge, MA: Marketing Science Institute.

xvii. Dowling, G. (2002). Customer relationship management: In B2C markets, often less is more.California Management Review, 44 (3), 87-104.

xviii. Dutu, C. \&Halmajan, H. (2011). The effect of organizational readiness on CRM and business performance. International Journal of Computers, 1(2), 106-114.

xix. Elahi, S. H., \&Hiedari, B. (2005). CRM. Tehran: business publication.

xx. Garth, S., Shepard, A., \&Podolny, J. (2001). Strategic management. New York: John Wiley \& Sons.

xxi. Hakkak, M., \&Ghodsi, M. (2015). Development of a sustainable competitive advantage model based on balanced scorecard. International Journal of Asian Social Science, 5(5), 298-308.

xxii. Hislop, D. (2013). Knowledge management in organizations: A critical introduction (3rded.). UK: Oxford University Press.

xxiii. Jayachandran, S., Sharma, S., Kaufman, P., \& Raman, P. (2005). The role of relational information processes and technology use in customer relationship management. Journal of Marketing, 69(4), 177-192.

xxiv. Jeon, S., Kim, Y., \&Koh, J. (2011). An integrative model for knowledge sharing in communities of practice. Journal of Knowledge Management, 15(2), 251-269.

xxv. Kasim, A., \&Minai, B. (2009). Linking CRM strategy, customer performance measure and performance in hotel industry. International Journal of Economics and Management, 3(2), 297-316.

xxvi. Liao, S.H., \& Hu, T.C. (2007). Knowledge transfer and competitive advantage on environmental uncertainty: An empirical study of the Taiwan semiconductor industry. Technovation, 27(6), 402-411.

xxvii. Liu, H.Y. (2007). Development of a framework for customer relationship management (CRM) in the banking industry. International Journal of Management, 24(1), 15-32.

xxviii. Mechinda, P., \& Patterson, P. (2011). The impact of service provider personality on employees' customer-oriented behavior. Journal of Service Marketing, 25(2), 101-113.

xxix. Mugenda, O.M. \&Mugenda, A.G. (2003). Research Methods: Qualitative and Quantitative Techniques. Africa Centre for Technology Studies, Nairobi, Kenya.

xxx. Orodho, J.A. (2000). Element of Education and Social Science Research Methods. Nairobi: Masola Publishers.

xxxi. O'Sullivan, D., Abela, A.V., \& Hutchinson, .M. (2009). Marketing performance measurement and firm performance: Evidence from the European high-technology sector. European Journal of Marketing,43(5 \& 6), 843-862.

xxxii. Pelham, A. M., \&Kravitz, P. (2008). An exploratory study of the influence of sales training content and salesperson evaluation on salesperson adaptive selling, customer orientation, listening, and consulting behaviors. Journal of Strategic Marketing, 16(5), 413-435.

xxxiii. Porter, M.E., \& Kramer, M.R. (2006). Strategy and society: The link between competitive advantage and corporate social responsibility. Harvard Business Review, 84(12), 78-92.

xxxiv. Reinartz, W., Krafft, M., \& Hoyer, W. D. (2004). The customer relationship management process: Its measurement and impact on performance. Journal of Marketing Research, 41(3), 293-305.

xxxv. Rumelt R.P. (2003). What in the world is competitive advantage. Policy Working Paper, 105(3), 1-5.

xxxvi. Shah, D., Rust, T.R., Parasuraman, A., Staelin, R., \& Day, G.S. (2006). The path to customer centricity. Journal of Service Management, 9(2), 113-124.

xxxvii. Sharabati, A.A. \&Fuqaha, S.J. (2014). Impact of Strategic Management on the Jordanian Pharmaceuticals Manufacturing Organisation Business Performance. International Review of Management and Business Research, 3(2), 668-687.

xxxviii. Sin, L. Y. M., Tse, A. C. B., \&Yim, F. H. K. (2005). CRM: Conceptualization and scale development. European Journal of Marketing, 39(11/12), 1264-1290.

xxxix. Sousa, R. (2003). Linking quality management to manufacturing strategy: An empirical investigation of customer focus practices. Journal of Operations Management, 21, 1-18. 
xl. Tracey, M., Vonderembse, M.A., \& Lim, J.S. (1999). Manufacturing technology and strategy formulation: keys to enhancing competitiveness and improving performance. Journal of Operations Management, 17(4), 411-428.

xli. Xu, M., Rohatgi, R., \&Duan, Y. (2007). E-business adoption in SMEs: Some preliminary findings from electronic components industry. International Journal of E-Business Research, 3(1), 74-90.

xlii. Yim, F., Anderson, R., \&Swaminathan, S. (2004). Customer relationship management: Its dimensions and effect on customer outcomes. Journal of Personal Selling \& Sales Management, 24(4), 263-278.

xliii. Zablah, A.R., Bellenger, D.N., \& Johnston, W.J. (2004). An evaluation of divergent perspectives on customer relationship management: Towards a common understanding of an emerging phenomenon. Industrial Marketing Management, 33(6), 475-489.

xliv. Zhu, Z., \& Nakata, C. (2007). Re-examining the link between customer orientation and business performance: The role of information systems. Journal of Marketing Theory and Practice, 15(3), 187-203. 